\author{
ЈОВАН М. ДЕЛИЋ* \\ Универзитет у Београду \\ Филолошки факултет
}

\title{
РОМАНИ КОРЕНИ И БАЈКА КАО ПРЕСУДНА ДЈЕЛА У РОМАНСИЈЕРСКОМ РАЗВОЈУ ДОБРИЦЕ ЋОСИЋА
}

\begin{abstract}
Два Ћосићева романа - Корени и Бајка - предмет су нашег разматрања као кључни, преломни романи у пишчевој еволуцији.

Кључне ријечи: поетски роман, сукоб, драмски потенцијал, солилоквиј, полиперспективизам, простор, природа, симболизација, раскол, дожвиљени говор, фантастични роман, антиутопија, идејна јерес, прелом, алегорија, парабола, романсијерска еволуција.
\end{abstract}

Издвојили смо два романа из опуса Добрице Ћосића - једног од најобимнијих и најамбициознијих и најостваренијих писаца у српској књижевности - да бисмо истакли њихов значај и мјесто у књижевном и интелектуалном развоју овога писца. Ова два романа - Корени и Бајка - типолошки су сасвим различити и различито су оцјењивани у српској књижевној критици и историји. С њима су наступиле крупне промјене како у Ћосићевом стваралаштву, тако и у српској, па и југословенској књижевности уопште, а нарочито у роману. Те промјене су изразите како на тематском плану, тако и на плану времена о којем се приповиједа, на плану приповједања, приповједачке перспективе, стила, а нарочито на плану погледа на свијет и историју.

Корени су од појаве 1954. године до данас сматрани за изузетно успио роман који је поетском и лирском снагом оплеменио причу, па се чак и данас, уз Деобе, често сматра естетским, а поготово поетским, највишим дометом Добрице Ћосића. Такво мишљење, рецимо, заступа Иван Негришорац. Ово је, уз то, изузетно читан роман који је и код публике и код критике имао велики, а и данас има лијеп успјех. Сасвим су биле ријетке књижевнокритичке замјерке упућене овом роману. 
Бајка (1966) је доживјела лијеп одзив критике, али је статус овога романа код књижевне публике до данас остао проблематичан. То је једини роман Добрице Ћосића који публика није прихватила; не барем са оним одушевљењем, радозналошћу и радошћу са којом су прихватани остали Ћосићеви романи.

Милан Радуловић, писац студије синтезе о романима Добрице Ћосића, оцјењује Бајку као наш најбољи фантастични роман, што је, вјероватно, претјерано, а Слободан Селенић види овај роман међу најзначајнијима и унутар Ћосићевог опуса, и унутар српског романа уопште. Дакле, Бајка има своје велике поштоваоце од угледа, имена и значаја. У предговору издању Корена и Бајке у антологијској едицији Десей векова срйске књижевности и Радуловић ће потврдити, па и појачати своју оцјену овог Ћосићевог романа, сматрајући да је Бајка „најбољи и најтирајнији роман Добрице Ћосића" [подвукао Ј. Д.].

Бајка је остала усамљена унутар Ћосићевог опуса. Тим путем писац даље није ишао. Фантастику ће препустити другима, а сам ће се вратити имагинирању националне историје. Ипак, Бајка има почасно мјесто у традицији нашег антиутопијског романа, а то наука о књижевности не смије занемарити.

Дубоко смо увјерени да су и Корени и Бајка романи од највећега значаја за књижевни, односно романсијерски, па и интелектуални развој Добрице Ћосића; за његову романсијерску, политичку и публицистичку судбину.

Корени су књига поетичког заокрета; чак књига бројних личних поетичких открића и повратка на извор и почело. С Коренима ће писац пронаћи ону почетну тачку у историји, у времену о којем приповиједа, и од те тачке ће кренути у свом имагинирању историје. Овај роман је данас гранични угаони камен у Ћосићевој романсијерској визији историје; у њему су коријени и почело те визије, Ћосићевог успостављања епохе. У Коренима је Ћосић открио и створио своје Прерово, свој књижевни завичај, свој златни књижевни рудник. У том роману је обликовао своје прве Катиће и Дачиће, које ће пратити кроз читав XX вијек, моделујући своју књижевну визију ипак свога стољећа. Тешко да би без Корена било Времена смриич.

У вези са Коренима помињу се најчешће два велика свјетска писца: Фјодор Михаилович Достојевски и Вилијам Фокнер. Помиње их, прво, сам Ћосић као писце који су на њега највише утицали, а уз њих и Оскара Давича, с којим је, у вријеме рада на романима Далеко је сунще и Корени - дакле, у вријеме свога романсијерског формирања - био у блиским, чак и присним односима и са њим свакодневно размјењивао списатељска искуства. Ту захвалност Давичу за пријатељство и сарадњу неће по- 
мутити ни доцнији драматични разлази на идеолошком плану. Трагови присуства прозног искуства ове тројице писаца на Коренима уочљиви су и већ препознати: тичу се чак основне прозне стратегије у овом роману. Давичо је могао утицати на лиризацију и поетизацију Корена; на стил, симболизацију и богатство тропа. Не носи ли знаменити Давичов роман наслов Песма? У вријеме рада на Коренима оба писца су се бавила загонетком унутрашњег монолога и субјективизацијом приповиједања. Њима треба додати и Лалића, који је несумњиво био ближи Ћосићу него Давичу, поготову када је ријеч о антиутопији и односу према ђаволу, односно Фаусту.

Ћосић је упозоравао на трагове руске литературе уопште на својим романима. И о томе је већ писано. Тако се генерацијски сукоб очева и синова, карактерисичан нарочито за Корене, доводио у везу са романом

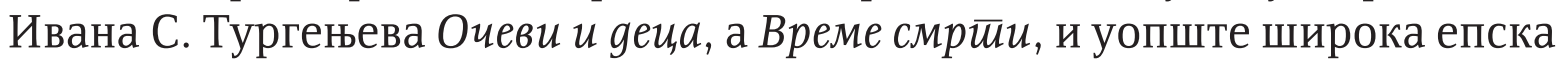
слика XX вијека, са Толстојем, прије свега са Райом и миром. Као млад, и несумњиво веома даровит писац широког замаха, скромног образовања и почетног читалачког искуства, Ћосић је, очевидно, пуно читао и веома брзо учио књижевни занат, и то и на класичној и на модерној литератури паралелно и истовремено, читајући и домаће и свјетске писце.

Охрабрење за поетизацију и лиризацију Корена Ћосић је могао добити од тада непознатог писца, кога је Ћосић у вријеме рада на Коренима откривао и читао - Милоша Црњанског. Милан Радуловић инсистира управо на Ћосићевом доживљају природе као блиском поетском доживљају Милоша Црњанског, а преко природе Корени добијају своју космолошку димензију.

С Коренима долази наглашена субјективизација и поетизација Ћосићевог приповиједања. Једва да се нађе понека реченица да није субјективно обиљежена, што је необично за роман који је доминантно писан у трећем лицу. Ћосићево треће лице у Коренима је варка; оно је потенцијално готово увијек прво лице. Отуда мијешање трећег и првог лица у истом пасусу, па чак и у истој реченици. То је поуздано знак субјективизације приповиједања, па и субјективизације самога трећег лица; знак унутрашње тачке гледишта чим треће лице, неосјетно и природно, „склизне” и пређе у прво, без штете по увјерљивост приче и причања. И то није само случај са једним јунаком и његовим гласом, односно свијешћу, већ са више њих.

Ријеч је о изузетно успјелој, најчешће мајсторској, употреби слободног неуправног говора, односно о доживљеном говору чије је треће лице изразито субјективизовано, на моменте чак и драматизовано. Ћосићев слободни неуправни говор прати ток јунакових мисли, заузима њихову психолошку, идеолошку и аксиолошку, а не ријетко и фразео- 
лошку тачку гледишта. Измјена тачке гледишта и промјена перспективе каткад личи на измјену драмских реплика, односно на прикривени дијалог или на измјену различитих, међусобно супротстављених унутрашњих монолога и становишта. Унутрашњи монолог Ћосићевих јунака у Коренима исказан је доживљеним, односно слободним неуправним говором.

Ауторски глас као „објективно приповиједање” готово да не постоји у роману. Роман је вишегласје јунака, борба њихових гледишта и становишта. Вјероватно ту треба тражити трагове романа Достојевског, под претпоставком да прихватимо Бахтинову тезу о полифонијском роману, мада је код Достојевског ауторски глас присутан и, према Бахтину, равноправан са другим гласовима у роману.

Из вишегласја јунака долази и полиперспективизам овога Ћосићевог романа, што га приближава Фокнеровом искуству, посебно роману Бука и бес. Али, за разлику од Фокнера, Ћосић не прелама исту грађу кроз различита виђења и различите свијести, већ се Ћосићеви јунаци међусобно споре развијајући радњу и жестоко се сукобљавајући. Свијет се сагледава из перспективе Аћима, Ђорђа, Симке, Вукашина, Николе, Толе Дачића. Свијет је позорница, а Катића кућа „хајдучко позориште”. Ћосић је - по односу према сукобима међу јунацима и по занимљивом, узбудљивом, па и драматичном сижеу - ближи традицији Достојевског. Вишегласје и полиперспективизам су - уз доживљени, слободни индиректни говор - доминантна структурална својства Корена.

Трећим лицем и слободним неуправним говором прикривени, али мајсторски остварени гласови најчешће су сукобљени и супротстављени, тако да Корени имају особине драмског романа, односно романа драме супротстављених и сукобљених свијести. Отуда жива и узбудљива „прича”, односно радња романа која се грана у више рукаваца. Драмски потенцијал - унутарња напетост и међусобна сукобљеност јунака - једно је од поетичких својстава Ћосићевих романа. Дешавања у кући Аћима Катића и око ње његов син Вукашин ће оцијенити као „хајдучко позориште":

Хајдучко позориште... Рат с Турцима пренет у рат за власт, у политику. А политика на трпезу и у постељу. [...]

Наказно политичко, „хајдучко” позориште одиграва се управо на Бадње вече, за празничном трпезом у кући Аћима Катића, па се празник мирбожања - општег измирења и породичне слоге - преображава у своју супротност, у пародију без хумора и комике, у вече драматичног, трајног и коначног породичног раскола. Разлог је доиста Вукашинова брачна постеља, његова женидба кћерком Аћимовог политичког против- 
ника Тошића. Политика је загадила и породичне односе, и трпезу, и постељу.

Зато описи јунака и ентеријера понекад личе на описе позорнице и на дидаскалије. Тако се наговјештава драма породичног раскола на Бадњој вечери у кући Аћима Катића:

... Нико не устаје. Са свеће, пободене у преломљен колач, капље восак. Слушају како капље и као да због тога ћуте. Сви се питају: зашто се ћути? Сви гледају мирно вретено воштане светлости, очекујући нешто што се слути над непоједеном свечаном вечером.

Одмах иза ове „дидаскалије” слиједи измјена прикривених гласова Аћима, Ђорђа, Симке и Вукашина. Приповиједање личи на филмско приказивање: као да камера клизи са једног лица на друго откривајући детаље на лицима, слике, покрете, чак и звукове - клокотање вина - и унутарње гласове јунака. Драма Бадње вечери у Катића кући се распламсава и ова брза измјена тачке гледишта то убједљиво дочарава:

Можда ови нешто знају? Аћим пређе очима по Симки и Ђорђу. У Симкиним крупним зеницама пламсају две мале свеће. Слутња му се згусну у страх. Припали и другу цигару. Никад овако. У овој соби, у којој се само једанпут у години вечера, кад Вукашин дође. Поглед му се пободе у гутицу између његових размакнутих и густих обрва. Љут је. Зашто? Моїао си gа јавиш gа йе иекам, чвор је сенка, а лице му је жућкасто, гутица на корену дугог носа ударац је нечије песнице. Зар је време такво да и Вукашина туку? Дошао да се пожали... Не, неће то. Такви смо ми. Тврђи од бреста. А леп. Њему би приличило и краљ да буде.

Гласан клокот. Ђорђе надушак испија дубоку и шарену чашу вина. $3 a$ мене никаg није нареgио gа се уйреїну санке. А gа су ми расйолуйили илаву на $\bar{u} y \bar{u} y$ ? Одоздо, оштрим млазом хвата очеву браду. Само њене две мало укосо управљене ракље. Он ... у кући тиранин, а преко плота мазан и сладак. Само докле?

Аћим се накашља. Сраман му је гласан клокот вина, и верује: Ђорђе из ината тако пије. Пружа Вукашину цигару да припали. Овај пали на свећу. Коса му запуцкета. Некакво му се велико зло десило. Зашто не одлазе?

Симка срете Аћимов поглед, руке јој пођоше софри да нешто узму, па се полако вратише на крило. Никад није дошао да јој макар прегршт шећера не донесе. Ако. Само кад је дошао. Ђорђе неће смети да је мучи као прошле ноћи. Удахну дубоко, шиљак светлости се пресави и само што се не прекину.

Вукашин међу прстима окреће цигару и загледа је. Сигурно су чули. Сви се чудно држе. Како да им објасни? Шта да му каже? Очеве очи осећа на себи. Он то не може да разуме. Неће. А ја морам...Кида влажан крај цигарете. То мора једном да се догоди. А после? Подрхтава. 
Подвукли смо она мјеста у којима прво лице проваљује у слободни неуправни говор субјективизујући сваку реченицу, исказ, пасус, што недвосмислено показује да је ријеч о унутрашњем приповиједању у којем сваки наведени пасус значи промјену тачке гледишта, увођење новога гласа и прикривене драмске реплике.

Нијесмо доследно пратили ни истраживали појављивање првога лица и његово мијешање са трећим, али је оно веома често. Забиљежили смо га на $18,32,33,48,49,56,59,189,205,247$. страни НИН-овог издања из 2004. године, али је ова појава много учесталија од наведених страница и заслужује посебно истраживање.

Однос међу ликовима романа може се описати као систем суко$\delta a$, и то „вјечних сукоба" који добијају митске и архетипске димензије. То је, прво, сукоб између два брата, Ђорђа и Вукашина, двојице Аћимових синова који су контрастивно постављени као антитетички пар; затим сукоб отац - синови (Аћим, Ђорђе, Вукашин); сукоб несрећних бездјетних супружника (Симка - Ђорђе); сексуално ривалство и сукоб господар - слуга, при том бездјетни господар и синовима богати слуга (Ђорђе - Тола Дачић); шири социјални сукоб и Аћимова буна; сукоби унутар самих јунака (Симка, Ђорђе, Аћим, Никола) све до њихове унутарње расцијепљености и раскола, тако да роман носи велики драмски потенцијал и плијени спојем лирске снаге и драматичне приче. Не само да је убједљива већ је и тачна теза да су Ћосићеви описи природе у Коренима уткани у значењски слој романа, посебно у пишчев систем симбола и лајтмотива. Тако је овдје брест, који је још из Василијевих времена пред кућом, симбол породичне мушке чврстине и срастао је с Аћимовим доживљајем себе и Вукашина.

Браћа, Ђорђе и Вукашин, контрастни су пар. Ђорђе је мали, слабо физички развијен, необразован, везан за кућу и имање, вјешт трговац, успјешан у стицању и умножавању дуката, али интимно дубоко несрећан, доминантно обиљежен својом јаловошћу, стерилношћу и неуспјешним односом са женама, несрећан у љубави и сексу. Отуда његов наглашен комплекс осјећања ниже вриједности, помијешан са непрестаним осјећањем страха и несигурности, промашености, неостварености и угрожености - да ће све његово припасти другоме, туђину, и да је његово стицање било лудо и узалудно. Према Вукашину осјећа мржњу и завист који долазе од страха да ће му млађи брат на крају узети све, а то осјећање вуче коријене још из дјетињства: Вукашин је од малих ногу био предмет очеве љубави и успјело дијете, док је Ђорђе личио на мајку и пао у други план због своје повучености и слаботиње. Дјечак је запамтио и до старости носио своје емотивне повреде, посебно оне које долазе од оца: 
Памтим све. Никад ме ниси узео на крило... Никад се ниси поиграо са мном. Ни пожелео срећан пут.

[...]

Гонио си ме да радим више него слуге. И Тола Дачић лепшу је младост имао од мене. Ни по оделу се нисам разликовао од слугу. Деди Луки лакше је било. Живео сам, као воденичарско псето. Главу и срце си ми згњечио Вукашином.

Своју несрећу Ђорђе све чешће потапа у ракију тонући у пијанство које се преображава у агресивност слабог човјека. Та агресивност је усмјерена према жени коју види као извор и узрок своје несреће, оптужујући је за бездјетност и страхујући од њене преваре и невјерства, па чак и од женине освете и своје смрти.

Вукашин је, за разлику од Ђорђа, налик на оца и очев миљеник и нада: наплав и знатно виши од брата, у очевим очима оличење мушке љепоте („А леп, њему би приличило краљ да буде”), изразито самосталан и одлучан. Европски образован - студирао у Паризу - и европски одјевен; елегантан да би му и министри позавидјели. Једном годишње, о Божићу, долази у Прерово; он је неко ко се чека и жели.

Браћа су сасвим различита и у избору жене: Аћим за Ђорђа бира Симку надајући се да ће му снажна, љепотом и тијелом обдарена снаха напунити кућу унучићима. Вукашин је у том погледу изразито самосталан: он бира жену за себе не марећи превише што је она кћерка Аћимовог најљућег политичког противника Тошића. Он ће свој избор и своју одлуку претпоставити вриједностима куће, завичаја, оца и очеве љубави, очеве политике, брата и снахе. Његов приватни живот је његова ствар и не дозвољава ником да се мијеша у његов интимни свијет, по цијену раскида с оцем и родитељском кућом. Његова политичка увјерења су другачија од очевих и преровских.

Вукашинови социјални и политички идеали су европски. Он би од Србије градио нешто слично ономе што је видио и доживио у Паризу. Њему су далеки и анахронични Аћимови политички погледи. Али Вукашин такође види да је не само тешко већ и банално бити Европејац у балканској чаршији, али осјећа дужност и потребу да нешто помјери и промијени. Он је носилац модерних идеја и има потпуно различите погледе на свијет, живот, политику и породицу од Аћима и Ђорђа. Он неминовно мора скинути гуњ и опанке и замијенити их ципелама и модерним европским одијелом. Одвајање је неизбјежно и природно, али је драматично и трауматично по све у кући Катића.

Али он је и непознатом кочијашу препознатљив као син Аћима Катића, јер умије да наређује као и отац му. Још откад је проходао, сви су видјели да личи на Аћима „и по снази и по нарави”. Зато је сепарација 
болнија по обојицу. Вукашин зна да њоме започиње свој нови живот. Он је човјек идеја који потискује сентименталност; сентименталност значи крај идејама. Вукашин ће подсјетити оца на његов сумњив систем вриједности, питајући га зар му није важнији он, Вукашин, од странке.

Вукашин је за Ђорђа небрати који тражи велики новац као свој дио имања, иако је од тог имања, и на њему стеченог новца, школован у свијету. И сам Вукашин осјећа да је крив за тај пакао што га је баш он изазвао и створио у родитељској кући на највећи хришћански породични празник. Чак ће и Симка запитати гдје је Вукашину душа кад на Бадњи дан дијели имање.

Отац је у сукобу с обојицом синова; с обојицом изразито незадовољан да ће, на крају романа, у апсани рећи Ђорђу, када он, због сина и жене, оставља Аћима без подршке:

А ја сам имао два сина и обојица су умрла. Сироти... Била су то добра деца.

Аћимови синови су, наравно, у животу, али су за оца већ сахрањени, јер су га вишеструко изневјерили: Ђорђе је јалови, не може да обнови породицу нити да остави потомство; Вукашин се отуђио од села, оца, гуња и опанака, оженио се Тошићевом кћерком, изазвао породичну свађу и диобу на Бадње вече и већ на Божић напустио родитељску кућу. Он је, уз то, починио и политичку издају и његов политички успон се подудара с Аћимовим посртањем. Истина, Вукашин ће иза сцене спасавати оца из апсане када је Аћиму пријетила истинска и права животна опасност. Али то Аћиму мало значи: он је видио, и у мислима пројектовао, Вукашина као насљедника у странци и на политичкој сцени; као браниоца сељаштва, одјевеног у гуњ и опанке. Вукашин је очеве идеале морао одбацити као анахроничне, конзервативне и често врло ризичне. Аћим накнадно схвата да је Вукашинова сепарација започела када га је први пут одвео у Паланку; наставила се синовим удаљавањем све до одвајања и раскида: све рјеђа и краћа писма; све рјеђи доласци у Прерово. Божићним породичним расколом руши се цио један свијет; то је крај Аћимовог доба; долазећи догађаји ће то само потврдити. То Аћим изнутра осјећа, па у њему одјекује нова мисао: „Ја више не постојим. Ја сам ишчупан."

То осјећање изненадног и неочекиваног обескорјењења својствено је преломним периодима и јунацима тих периода. По томе Аћим Катић није нов у српској књижевности, али је нов као успио, веома добро и оригинално замишљен и остварен књижевни лик.

Ђорђе је задовољан очевом и братовом свађом, породичним расколом, ма колико и сам био на губитку. Он губи и брата, и дио имања, 
односно дукате, што доживљава као болну неправду. То показује колики је његов, од дјетињства храњени, негативни емотивни набој према Вукашину.

Породични раскол се дочарава и неколиким снажним, визуелним и звучним, готово филмским сликама. Иза Вукашина остају отворена врата; у кућу улијеће хладан зимски вјетар, а негдје лаје псето „љутито и изгубљено". Свака од ових слика је сугестивна и симболична; свака шири око себе поље асоцијација, што ће рећи да је свака вишезначна.

У ноћи раскола, у којој га се отац одрекао, Вукашин осјећа да је отац „суров и снажан” и да је одсудне Бадње вечери изгубио све. Мајсторски је ухваћена и симболизована Вукашинова сјенка посљедње ноћи у очевој кући, пред одлазак на починак:

Његова сенка, полегла по патосу, успела се зидом до прозора и на њему пресекла главу. Дуго стоји.

Та сјенка је много рјечитија и успјелија од свих црних птица што се у мраку привиђају Вукашину и налијећу на прозор, и од „безглавих зверки мрака" испод кревета и из углова собе, спремних да скоче на њега.

На Божић ујутру Аћим изјахује у ливаде да не би гледао посљедњи Вукашинов одлазак из родне куће. У тој слици је искоришћена флорална симболика, мада је преломљена и дата кроз Ђорђев доживљај:

Аћим полако изјаха на пут. Ђорђе гледа за њим. Црни се на снегу. Скресано стабло шљиве.

И сам Аћим је изненађен промјеном свога лица у огледалу још прије божићњег породичног раскола: то лице се нагло измијенило и остарило да је хтио четком да удари тога непознатог старца и да разбије огледало. А док се својевремено расправљао с Вукашином око његовог европског одијела, чуо је како је ластавица - птица селица - двапут тупо лупила о прозорско стакло, разљућено и жалосно цијукнувши.

Све ове слике имају снажну лирску и симболичку вриједност и све истовремено показују тешко стање у којем се јунаци налазе.

При крају романа Аћим зна да Вукашин има двоје дјеце, па крадом уходи синову кућу, не би ли срео и упознао унучад. Могао је само сумњичаво да наслути да би дјевојчица „с трњем у очима” могла бити његова унучица. Вукашинова дјеца су му непознати туђинци, а Адам је туђа крв, калем на породичном стаблу. Аћим ће тек на самом крају романа загрлити Адама, пошто је дјечак остао сироче без мајке и једва преживио опаку болест, иако је малиша показао храброст према пандурима и емотивну приврженост дједу кад су му дједа одводили у апс, уједајући их за руке и чупајући за рукаве. 
Ђорђе остаје слаб, јалов и пред Аћимом неодрастао чак и у зрелим годинама. Када излази из апсане, „Ђорђе бацака ноге као дете кад почиње да хода" и бива лак плијен Раке апсаџије за уцјену и манипулацију. Његова непослушност - одбијање да донесе оцу новине када се враћа из трговине - више је инфантилна него што је озбиљна побуна против очевог ауторитета. Отац и син се у апсани сударају очима: „Роговима мржње. Роговима немоћи.” Ђорђе је у том судару „слаб и немоћан”; Аћим - прејак и силовит.

Ђорђе је најбоље и најпажљивије индивидуализован лик у Коренима, сагледан из највише углова и перспектива, и у најразличитијим односима и сукобима: са братом, са оцем, са женом, са Толом Дачићем, са Николом сагледан и Николиним очима, па чак и очима учитеља Андре. Ту су још механе и механџије, београдске жене. Нико није са толико страна освијетљен као Ђорђе.

Ђорђе је, у очевим очима, од дјетињства „баксуз”, жгољав, ћутљив, издвојен; са дјецом се није играо; завлачио се у сењак и тамо скривао, не одазивајући се на позиве; претурио би Вукашину вечеру; подмукло би га гурнуо у бару да би му испрљао одијело. Аћим признаје да је Вукашина одувјек издвајао; да му је куповао лепше ствари, и то осјећа као свој гријех, јер је тиме више осамљивао Ђорђа, „а са̂мо дрво убије ветар”.

И снаху Симку је Аћим више волио од Ђорђа. Био је то његов избор, по његовим критеријумима - жена која ће да рађа: крупна, боката, висока, витка; плови двориштем „као усправан вал”.

Аћим је „цикнуо од радости кад је видео Симку с набреклим недрима" и намах одлучио да му буде снаха. Та привлачност је двосмислена, што ће се открити и касније, када се син показује као неплодан, а на Симки се види умор и незадовољство од искиданог сна, па се у Аћиму пробуди старачка срамотна жеља за снахом. То додатно несвјесно компликује однос према Симки и Ђорђу.

Ђорђе ће приговорити оцу да му је он одабрао жену која се показала бездјетном, а да би се приближио Симкиној мајци Милунки; да је он - Ђорђе - радио на имању и стицао, а Аћим расипао на Вукашина и политику. Најзад, Ђорђе ће сурово и не сасвим праведно разобличити Аћимову љубав према синовима - то је само други вид љубави према себи, потврда свога значаја, важења и моћи:

Ти што једино на свету волиш себе. Једино себе волиш. А синове волиш као што се воле брзи коњи и кад су најбржи у селу. Волиш их само ако ти други завиде на њима. Ако ти цела Србија завиди на њима. [...] 
Ту себичност Аћимову, али као себичну храброст, истаћи ће и учитељ Андра као једну од кључних Аћимових особина: том себичном храброшћу Аћим је мучио и себе и своје синове.

Ђорђа видимо на почетку четврте главе романа, у апсани, очима учитеља Андре, у тренутку када је сломљен и када жели да напусти оца у апсани. Уласком сломљеног човјека у апсану почиње четврта глава:

Андра схвати шта се догодило, јер Ђорђе уђе полако, неодлучно, уђе као пребијено псето, глава му спарушено виси на омршавелом врату, и тако се куштрава и сува преломила на црном зубуну, из кога млитаво теку два пртена рукава, а не руке, да се Андри чини: пред њим стоји човечуљак преклан на потиљку. Уплашено, тихих напрегнутих покрета, зби се у сам угао, где је сумрак гушћи.

Ту је личност убијена; исцурила је из одијела; остале су да висе само крпе. А на другој страни Аћим, који постаје „све страшнији у својој занемелости”; „човечина чија му [Андри - Ј. Д.] је храброст увек била непријатна". Када се Аћим окреће Ђорђу, окреће се - тако Андра види - „испражњеној кошуљи и зубуну што још увек стоје у замућеном видику, где цвокоће сува храстовина”. Ђорђе је са сваком ријечју „све мањи и лакши", па би се од једне праве ријечи „смуљиле [...] те крпе на једну гомилицу као поред кревета бачена кошуља у суботу вече".

То је Аћимов син, док је Аћим једини који се не боји вјешала; њему је стало да славно умре и да га по смрти памте, али му судбина није била наклоњена. Аћим и Ђорђе - то су у Андриним очима двије најудаљеније могућне личности, а отац су и син; истински антиподи.

Самоме Ђорђу отац је био „страшан у својој смирености”, која у апсани има нечег нељудског, и Ђорђе се бојао „тог нељудског у Аћиму”; те неприродне храбрости, коју је тек у затвору ближе упознао, а коју је учитељ Андра протумачио као један вид Аћимове себичности.

На крају романа Аћим смјењује уморног Ђорђа крај постеље малога болесника Адама, и у себи, унутрашњим монологом и нијемим обраћањем, кроз сузе, своди свој разочаравајући негативни животни биланс. Осјећа се потпуно сам и напуштен, без икога свога. Синови су разочарање и породична издаја. Њега, који је градио ауторитет на страху, нико се више не плаши. Остао му је једино тај болесни дјечак, сироче и туђа крв. Аћимов кратки унутрашњи монолог од половине пасуса прелази од трећег на прво лице једнине:

[...] Чује како мало срце куца. Удише мирис младе коже и плаче. Нису хтели да ме убију. Нико ме се више не плаши. Али ти ћеш да порастеш. Још једино тебе имам, иако ниси мој. Ниси моја крв, али презиме имаш моје. То је мало. То је много. Научићу те да их мрзиш. 
Тада је Ђорђе први пут видио свога оца да грли Адама, што нијемом исказу посљедњег Аћимовог унутрашњег монолога даје додатни значај.

Аћим, очевидно, свој ауторитет и успјех гради на негативним осјећањима - на страху и мржњи - и то животно искуство жели да пренесе на Адама, иако су га управо та осјећања, као погрешан темељ његовог односа према свијету и људима, довела до пораза и на интимном плану - у породици, у односу према жени и синовима - и на друштвеном плану, у политици и бунама.

Заспали, болешћу исцрпљени Адам, Симкино сироче, постаје готово у истом часу двоструки насљедник: Аћимов, који га је тестаментарним сузама и загрљајем прихватио за свога унука, и Николин, који му оставља причу о Катићима и о Адамовом рођењу, а дјелимично и о себи. Он се тада - без своје воље, недужан, болестан, несвјестан, сирот и уснио - укорјењује и постаје прави Адам, нови почетак. Оба насљеђа су тешка.

Адамово коначно укорјењење у породицу Катића јесте и обнова породичне судбине, односно приче о Ђорђевом дједу и Аћимовом оцу - Луки Дошљаку; приче коју и Аћим и његови синови носе у памћењу и сјећању и које се опомињу. Та прича у роману постаје лајтмотив; добија судбинско значење варирањем и преламањем кроз свијести и различите перспективе главних актера - Аћима, Ђорђа и Вукашина. И у том смислу Адам јесте прави Аћимов насљедник, својим зачећем и рођењем. Нови Лука Дошљак не улази у газдаричину бездјетну постељу четрдесет први дан од газдине смрти и нестанка, како је то био случај са Катом, Василијем и Луком Дошљаком, већ Симкином жељом, осветом и насушном потребом за укорјењењем у кући и породици Катића. Аћимово увјерење да је он и корјен и стабло показује се као варка, јер се прича о Луки Дошљаку поновила, са новим јунацима и у новим околностима.

И Никола је - због своје жеље, љубави, чежње и заштитничког односа према Симки - у латентном сукобу са Ђорђем. Он ће рећи Симки да је несрећа јаловости у Ђорђу, а не у њој, а онда, у вредносно и емотивно обојеној реченици, донијети суд о Ђорђу: „Он није мушко, он је слама.” Николини судови имају посебну тежину у роману, па се овај наведени може односити на Ђорђа као на личност у цјелини. Ђорђе је „слама" и у односу према Аћиму. Кад Аћим диже буну и војска иде на Прерово, Ђорђе се опија у „Орачу”, а потом лежи у кући, пијан и сакривен, док трају хапшења и одмазде.

Посебно пажљиво је грађен Ђорђев однос са слугом и црквењаком Толом Дачићем. То је однос блискости и супротности, пажње и сукоба. Заједно су одрасли, заједно војску служили, заједно ратовали. И очеви 
су им били блиски све до ране смрти Толиног оца. Двије генерације су изградиле међусобно повјерење. Они су, међутим, изразите супротности, па је Толе Ђорђу мрзак због његове подсмјешљивости, али га стално води собом као поузданог пратиоца на трговачким путовањима која трају недјељама, а пуна су ризика и непредвидљивих замки и опасности. Ђорђе је слаб, „преклан”, човјек „слама”; Тола је крупан, наочит, мужеван, шарених очију, изразито снажан, отац тројице синова, а жена је пред порођајем са четвртим бременом. Ђорђе је газдински син и газда, Тола пуки сиромах и слуга. Ђорђе је оличење начела стицања и дуката као метонимије тога начела; Тола - начела рађања синова. Зато је Ђорђе подозрив према Толи и осјетљив на његове заједљиве и подсмјешљиве примједбе. Тола ће по повратку с путовања добити мушке близанце; Ђорђе - двоструку породичну свађу. На Божић су обојица губитници и губици их зближавају; Толи умире „леви” близанац, а Ђорђу је брат напустио родитељску кућу: обојица добро знају и осјећају шта и кога на Божић, дан рођења Богомладенца, сахрањују. Дан рођења Младог Бога преображава се за обојицу у дан тешких губитака. Управо у том дану Ђорђе је спреман да поклони Толи све што му треба око сахране. Ђорђе потом моли Толу да му поклони једног дјечака како би га посинио и учинио својим насљедником, што Тола не допушта. Није онда чудо што ће пијани Ђорђе наговарати Симку да роди баш с Толом Дачићем, а онда је због тог свога предлога бездушно злоставља.

Тола ће се споменути Ђорђа у својој јововској распри с Богом око тога што баш њему узима сина. У свом псовачком гневу он и Бога, као и газду и комшију Ђорђа, оптужује за јаловост. Од Ђорђа Бог нема шта да узме: „Јалов је као црн јасен.” Бог може да узме дијете само ономе коме га је и дао, па Тола у губитничком гњеву и болу изравнава рачуне с Богом као са комшијом, са неким чак и физички блиским и надређеним, оптужујући их обојицу.

Тола ће оплодити Симку и тако побиједити у расправи са Ђорђем око дилеме: дукати или рађање. Адам ће бити син њих обојице - Ђорђев насљедник и калем на породичном стаблу, али и шести Толин биолошки син. Баш у том шестом - у Адаму - могу бити измирена оба начела: и начело дуката, и начело рађања. Зато ће при Адамовом рођењу њих двојица, оба брижни, сједити заједно и разговарати. Трећа глава, у којој се тематизује рођење Адамово, завршава се Толином дионизијском свирком у јабучару, односно тријумфом рођења.

Нешто прије тога, док се Адам рађао, Тола се ретроспективно сјећа дјечаковог зачећа и јединог сексуалног односа са Симком. Тако је ова еротска епизода релативно дискретно испричана на два мјеста у роману, из двију преспектива. 
Најзад, на повратку из апсане, док у селу влада помор, Ђорђе затиче Толу у својој кући, поред болесног Адама, како се бори за његов живот и сасвим природно и предано му привија и мијења ракијске облоге. Нимало га не збуњује нити изненађује Ђорђев долазак: Адамов живот је у тим тренуцима обојици пречи од свега.

Свакако, једна од средишњих осовина романа Корени јесте релација Ђорђе - Симка. Њихови контрасти и сукоби дају посебну драмску и психолошку димензију овом роману. Симкин лик је веома брижљиво и из више углова моделован. Симку, видјели смо, Аћим бира за снаху, по критеријуму плодности, еротске изазовности и тјелесне привлачности. Она је оличење плодне женске љепоте. Када осјети синову јаловост и Симкину брачну несрећу, у Аћиму се буди латентна и потиснута жудња, коју он успјешно контролише, али је с осјећањем гријеха препознаје.

Симкина „набрекла недра" - како их види Аћим, загрљени мјесеци њених дојки - како их замишља Никола, „чврсте, крупне, топле дојке" које је Ђорђе дуго с радошћу осјећао као своје, са̂мо су средиште њене еротске, животодајне, изазовне снаге и привлачности. Никола ће завидјети Адаму што ће гристи те сисе за којима је он, старац, толико неприлично жудио. Тјелесна и еротска снага је оно што издваја Симку и што је везује за њену претечу - Станковићеву јунакињу Софку из Нечucие крви. Ђорђе памти како се на његовом брачном ораховом кревету „на њега сјуривала Симкина необуздана пожуда”. Зато Ђорђе зна да Симки не могу помоћи никакви манастири ни молитве. Зато њега мучи неописива љубомора, све тежа и жешћа како се увјерава у своју јаловост.

И Симка је опсједнута својим тијелом, прије свега дојкама: „с уживањем и поносом” гледа „у своје крупне дојке које су бежале једна од друге и надимале кошуљу". Она машта о мушкарцу који ће је оплодити, истовремено познатом и непознатом; о „жељеном знанцу што је понекад посећује пред сан". То кратко уживање у себи јавља се у тренуцима купања, лежања у води, концентрације на своју тјелесност:

Дуго је лежала непомична, уживајући у себи, безименом мушкарцу нудила груди, трбух, удолину бутина, нудила себе невину са јарким жељама, нудила снажним рукама, мишићавим, длакавим, нудила се некоме коме је сваки превој на телу знала, само лице никако није могла да му види, том жељеном знанцу што је понекад посећује пред сан, и никад није сама у кревету.

Али и тај „жељени знанац" о коме сања, и само њено тијело, њен однос према себи и својим дојкама, усмјерени су на рађање, на будуће дијете коме ће бити пуна уста раскошних Симкиних дојки и мајчиног млијека. Симкин ерос је животодајан и усмјерен на оплођење, рођење, 
дојење дјетета: „[...] узела је у руку десну дојку па се, гледајући у крупан, таман вршак са смеђим колутом на купастој белини, насмешила, друкчије него обично: није желела Ђорђеве и оне мушке прсте на њему, вршак и његово смеђе дно, од струјања, чинило јој се - млека, најежили се ситним бобицама, сличним семену дивље метле. 'Пуна ће му уста бити', помислила је замишљајући како јој влажна и мека детиња уста цимају дојку и жудно пију млеко. Снага јој се сјурила у стопала, још боса и влажна. Неколико тренутака трнула је у малаксалости."

Прилазећи манастиру, гдје ће се исповиједити и молити за рођење дјетета, Симка смирује своје узбуђење и своје срце притиском на лијеву дојку. Ту су све команде њеног емотивног и духовног живота - у дојкама и њедрима: „[...] Привидело јој се да звезде светлуцају на самом крсту, па је свом снагом притиснула леву дојку не би ли смирила срце и сачекала мајку да и она пође напред."

Николин однос према Симки у знаку је контролисане, старачке пожуде, али и њежности и заштите. Никола је нијеми свједок Ђорђевог злостављања жене, што одређује његов однос и према Ђорђу и према Симки. Док је Ђорђе у апсани, а тешка болест пламти у Катића кући захвативши и Симку и Адама, гранична ситуација, близина смрти и одсуство забране и ауторитета - и Аћим и Ђорђе су у апсани - омогућавају слободније испољавање емоција, па Толина брига око Адама и Николина о Симки дјелују и као племенит чин. Иза тога је Толина очинска везаност за дјечака који се бори за живот и Николина скривена и снажна љубав према Симки. Он у њој гледа остварење идеала жене о којој је маштао у младости и носи је на рукама малаксалу и болесну у постељу:

[...] Откако ју је спустио на кревет, малаксалу и без свести, ноћи проводи уз њен кревет. Болесна и немоћна, без мужа и свекра у кући, она је први пут припала њему: може поред њених ногу да седи докле жели и да гледа колико хоће; може, кад јој ставља облоге, прстима да купи росу с њеног чела; може да јој прича оно што пре болести никад није смео да јој каже. Сме да се љути и да је кори што се Толи дала. Све може и сме, јер она ретко долази свести.

А када Симка умире, Никола јој завлачи руку у још врела њедра, с накнадном свијешћу да чини злочин и светогрђе. Када се Симкине дојке охладе, он осјећа као да их је заклао; као да је починио посљедње убиство. Затим ће мирно и прибрано саопштити Ђорђу да му је жена умрла.

Послије Симкине смрти Никола мора да оде из Прерова: прича о Адамовом рођењу и о Симки је завршена. Нестало је Николино небо са два загрљена мјесеца. Ни Аћиму више није неопходан; Никола слути његов брзи крај. Он мора кроз јарак, па преко Мораве, у неизвјесност. 
Ђорђев повратак с пута, из трговине, са Толом Дачићем, пред Божић, пресудан је за однос према Симки и за ток живота и систем односа у кући Катића. Ђорђе је први пут осјетио да га дукати жуље, да га не испуњавају задовољством које доноси стицање и први пут је увидио колико је рађање вриједност изнад стицања; колико су дјеца значајнија од злата и колико је - мјерено тим критеријумима - Тола Дачић вреднији и супериорнији од њега. Први пут се суочио са испразноћшу свога живота, тешког и суровог, у страховима и опасностима од пљачкаша и разбојника, без крајњег циља и насљедника, са сазнањем да му душа на свиње смрди, да се његов живот мало разликује од живота његових слугу. Промјена система вриједности доводи до драматичних ломова и у човјеку, и у односу са другим људима. Сазнање да кеса није увијек ни у свему мјера ствари, да дукати нијесу ни једина ни највећа вриједност, а да је рађање изнад стицања, из темеља мијења однос и према жени, и према оцу, и према брату, па и према слуги Мијату, као и према псу: на све је љут и сви су му криви. По повратку с пута он иде из сукоба у сукоб. У њему се појачава ионако веома снажно осјећање страха, а са њим и несигурност; јавља се потреба за разарањем и аутодеструкцијом - да све треба спалити, да своју несрећу треба потопити у алкохолу, да жену треба тући баш зато што је лијепа и изазовна, па је и други желе. А он најбоље зна колико је Симкина пожуда неуморна; да јој је лице сурово, а очи немилосрдне.

Јавља му се помисао да га жена вара, да се можда везала с неким од слугу, да ће га убити како би га уклонила и располагала његовим имањем, попунила његову постељу с другим човјеком и постала мајка. Зато је треба отјерати. Ђорђева слабост и страхови највећи су узроци његове агресије. Кад је пред најрадикалнијим одлукама, он је најслабији: „свалио се на јастук као сасушена махуница".

По повратку с пута Ђорђе улази у свој лични и у породични пакао. Његова јаловост и мишеви у подруму казују му да ће све ојаловити и опустјети. Ђорђе оптужује Симку да га је сатрла; да нема ништа од живота, осим дуката и муке; да је он „угашен угарак” и камен.

Симка одмах осјећа да јој се муж никад није такав враћао с пута, па се и њој самој њен живот показује другачијим, стварнијим и страшнијим. Чекала га је три недјеље и љуто га се ужељела гледајући са поносом своје крупне дојке испод кошуље коју би за њега облачила, да њега дочека, а сада се пита - док он сједи нијем и непомичан, дебелим сукном окован - како је могла да га таквог пожели? Петнаест година бездјетног брака било је петнаест година чекања у лудом сатирању и пословима.

Тек послије првих батина које је примила од мужа, Симка може да сагледа свој живот у правом свијетлу, у свом унутрашњем монологу. 
Ђорђе лежи у кревету у своме одијелу и хрче; „никад јој није био тако гадан - ружан као ове ноћи". Симка га осјећа као казну којом су је казнили мајка и Бог.

Симка осјећа брачни кревет као гроб, како ће га касније именовати и Ђорђе: „Док сам се ја у овом гробу по ваздугу ноћ превртала као црв на жеравици, ти си се ваљао по туђим постељама. За дукате, и ти, тако ситан и грдан, могао си с лепотицама да спаваш. А ја те чекам... По десетак вечери забадава сам облачила чисту кошуљу, а тебе нема. За тебе се спремала, а ти дођеш па заудараш на механчине, оборе и коње. А да си бар тада могао жељу да ми одмалиш. Узимала сам те у наручје и пела на себе, као што се дете пење на коња. А ти ме, јаду, штипаш, уједаш као мало куче, само ме наљутиш и оставиш. Од таквих као што си ти не би ни на ђубрету клијало! Па ме сада бијеш и мучиш, Турчине. А у шта ће мени да прође ноћ! Спаваш и хрчеш, хрчеш..."

Николин коментар Симкиног брачног живота, изречен Симкиној мајци, звучи метафизички безнадно:

Када би све жене живеле као твоја ћерка, Бога не би било.

Природно је онда што ће из Симкине подсвијести изронити Толине шарене очи. Адам ће бити Симкина освета и укорјењење.

Помисао на Толу и на његове шарене очи јавља се у Симки тек послије лома с Ђорђем и понижавајућих, незаслужених и бесмислених батина које је од њега добила. Рођење је Симкин једини излаз и спас. Бездјетну ће је Ђорђе отјерати из куће заједно са мајком Милунком, а нико не чезне да их прихвати. Симки је прељуба једини излаз, и то са човјеком шарених очију, чија жена рађа само синове. Те шарене очи су, очито, и раније живјеле негдје дубоко потиснуте у Симкиној подсвијести, јер израњају изненадно, тако и толико да изненађују и саму Симку, а затим је потпуно освајају:

А онда више није видела ни Ђорђа ни себе: лепа је и још млада. Над њу се надноси лик... Шарене очи. Зар он, зар с њим? Зачуди се, не, брани се, а он јој прилази све ближе, припија се уз лице, ураста у главу и у мраку истискује свест.

Симкина жеља за човјеком шарених очију јавно се испољава као брига за његов живот у Аћимовој буни и страх да му четири сина не остану сирочад. Док Тола цима црквеним звоном на узбуну, мисли шта ли је то Симка хтјела да му каже. Тола зна да је „Ђорђе јалов као црн јасен” и да је Симки потребан син. Симкина брига за Толине синове је скривена брига за самога Толу; брига праћена знацима њежности и жеље. 
И сам Ђорђе ће, истина - сасвим пијан, наговарати Симку да зачне са Толом, због чега ће је касније тријезан мучити. Тај пијани подстицај није занемарљив у мотивисању Симкине прељубе.

Симка је прије одлуке на прељубу покушала све да очува кућу и брак. Петнаест година је чекала зачеће. Одлучује се на искорак из брака тек када муж у својој немоћи почиње да је понижава батинама, оптужујући је за бездјетност и, заједно с Милунком, изгони из куће.

Оно што је мање увјерљиво у овој љубавној причи јесте да се прељуба догодила само једном и да је њен резултат Адамово зачеће. Страсна, незадовољна, чулна и пожудна Симка и снажни Тола шарених очију не римују се понајбоље са овом посном статистиком. Писцу је, очито, стало да у први план истури Симкину жељу за рођењем и материнством и као исконским нагоном и као јединим излазом из ужаса бездјетног брака у којем је означена као кривац. Сам чин прељубе не припада најбољим и најувјерљивијим сценама у Коренима.

Посебно је занимљив Николин лик у Коренима, а његова композицијска функција може бити чак и проблематична. Роман се отвара Николиним солилоквијем који има функцију пролога; тек послије њега слиједи „Глава прва”, односно долазе укупно четири главе романа. Николин солилоквиј изразито је поетски, лирски, са наглашеним присуством тропа, испричан досљедно у првом лицу једнине. Ту привилегију - да приповиједа у првом лицу - има само Никола, и то на почетку и на крају романа. Наиме, при крају четврте главе, пошто је прича о Катићима завршена, Никола поново преузима и закључује приповиједање, опет у првом лицу, градећи тако неиздвојен и ненаглашен лирски епилог романа. Николин пролог има непуних пет, а епилог нешто преко шест страна текста, што ће рећи да су приближно исте дужине. Николин глас, дакле, гради својеврстан прстен око романа; уоквирује роман, издвајајући се и тоном, и првим лицем, и лирском, поетском природом, и фигуративношћу.

Сажет више као скица, као низ личних јунакових реминисценција, Николин животопис се може резумјети као парабола о човјеку прогнанику на земљи. Рођен је - саопштава у посљедњем пасусу романа - 9 . јануара 1811. године, али одбија да каже мјесто свога рођења и своје презиме. За себе вели да је „први рудар Србијице, старац с гороломничким гласвом и житељ без гроба", који је безмало испунио својим животом читаво деветнаесто стољеће. Сироче без родитељских гробова; син оца кога су Турци набили на багремов колац, па нетрагом уклонили - бацили или закопали - његов леш, и мајке, која је полудјела чувајући мужевљево мученичко тијело, руку изуједаних од гладних паса луталица који кидишу на крв и људско тијело; мајке која је нестала негдје 
у трагању за мужевим гробом; чобан попових прасића који се уз попа описменио; први рудар Србије који је за златом трагао, а злато није нашао; бунџија и ратник који није постао војвода, пандур, шпијун и порезник који у државном послу није нашао смирење нити је стекао чиновничку каријеру; стајао је пред Гарашаниновим вратима, па до књажевог коњушара догурао, „а даље ни макац”; неукоријењени старац без дома и порода који много памти и зна, добро види и просуђује, снажни, ћутљиви црнорукац који је ноћу ножем решавао туђе спорове; усамљен српски Одисеј без Пенелопе и Телемаха или Ахасфер који „гази по овој нашој каљогажи између три реке". Никола носи у себи искуство и зло цијелог XIX стољећа. Његов завршни монолог, као и његов „летопис", адресован је на малог Адама Катића, као свједочење о његовом - Адамовом - идентитету и доласку на свијет, о његовом поријеклу и корјенима и, на крају, као свједочење и о себи самоме. Зато је завршни Николин монолог нешто другачији, „предметнији”, од пролога и адресиран је на Адама Катића. У њему је више информација о самом Николи него у цијелом роману.

О једном Никола не говори - не расвјетљава Адаму свој однос с Аћимом Катићем. То је нека страшна и крвава тајна:

По мом предсказању, Аћим неће дуго, и нек не брине, нашу тајну нећу одати. То што је између мене и њега остало, нико неће сазнати. Много је страшно и крваво било.

Никола долази у Прерово зими, по младом леду на Морави. За њим су гореле шуме и пут. Иза њега је ватра, а пред њим је лед, млади лед на Морави. Њему је у шанац улетјело и ту експлодирало топовско ђуле. Гледао је како избезумљено трчи и жив гори запаљени ован. Он бјежи од ватре, преко леда. Он „страх чује” како се гусне и расте док не букне уз прасак и ломљаву. Ћосићеви јунаци живе у страху или у близини страха, чак и када су, као Никола, оличење храбрости и одлучности. Никола је учесник Тимочке буне који је нашао уточиште код радикалског првака Аћима Катића, у чијој кући има пристојан, готово повлашћен статус. Он нема положај слуге: њему се служи храна као и другим газдама Катићима. Смјештен је у кући Катића, додуше у подруму, тачно испод спаваће собе супружника, Ђорђа и Симке. За њега је изразито везана симболика простора: бјежи од ватре, прелази преко младога леда на Морави и поново ће, на крају романа, прећи ријеку у супротном смјеру. Прича, радња Корена и вријеме о којем се у роману приповиједа смјештени су између два Николина прелаза преко ријеке у супротном смјеру - између његовог доласка у Прерово и одласка из куће Аћима Катића, по тами, кроз јарак, у неизвјесност. Он живи у подруму - најдоњем и нај- 
тамнијем дијелу куће - и припада доњем, хтонском свијету који доноси смрт. Нож, физичка снага, ноћ, мрак и ћутање главно су његово оружје. Изнад њега је плафон који га одваја од Симке и Ђорђа: то је његово небо са којега га обасјавају два бијела, загрљена мјесеца. Изнад њега је Симка, предмет његове старачке еротске жеље, недостижна жена на небу изнад његових очију, а два мјесеца су њене дојке за којима Никола чезне. Оваква полускривена просторна позиција омогућава Николи пун увид у породични живот Катића, а нарочито у несрећну брачну драму Ђорђа и Симке, што снажнога старца још више везује за несрећну и сексуално незадовољну жену.

Николина позиција је, дакле, вишеструко привилегована, мада његова припадност доњем свијету сугерише опасног човјека који доноси смрт. Он то и јесте; он то и чини, ноћу, у мраку, тајно и ћутљиво, ножем, непогрешиво, савршено и без трагова. Он је - то се више слути и наговјештава него што се открива - црна рука Аћима Катића; човјек мрака, ноћи и доњег свијета. Никола зна, види и чује више од осталих. Статус у Катића кући налаже му тајне разговоре с Аћимом. Иако интензивно живи и злочини ноћу - у подрумском мраку Катића куће проводи највећи дио времена - он најбоље познаје Прерово, односе и збивања у њему, а несталност живота, честе промјене посла и мјеста живљења, скитње и сеобе омогућиле су му да „као свој кожух познаје [...] ову Србијицу”, земљу која се спомиње у деминутиву, чиме се изражава однос присности, али и просторна ограниченост те земље између три ријеке. На том простору живот је несигуран и трагичан: гробља су увијек млада, а људски вијек кратак. Тај простор се три пута празнио и обнављао, огњишта се гасила и мијењала, а промјеном огњишта „и нарав ти се мијења”. Живот је привремен и кратак, с мишљу усмјереном на данашњи дан и на зло које он носи, па та мисао не досеже ни до сјутрашње зоре, а камоли до некакве будућности. Зато је једини Николин ослонац - нож.

Николин живот у Катића кући губи смисао Симкином смрћу: нестало је биће његове чежње и његове заштите, биће неостварене љубави; смрћу жене се завршила једна брачна драма о којој је он из подрума свједочио. Са Симком је умрла и прича о Катићима, барем што се тиче теме корјена. Аћим коначно прихвата тућу крв за унуче и на крају романа по први пут грли Симкино сироче. Никола се обраћа Адаму својим завршним монологом именујући Симкиног сина и за свога насљедника, јер је он „и крв матере своје покојне”.

Николино причање потврђује смисао Шехерезадиног архетипа прича и причање су својеврсна Николина одбрана од смрти: „Причам да не бих баш сасвим умро". Задовољство које доносе прича и причање је и у доживљају који изазивају код слушалаца, и у трајању приче. Сачувана 
прича побјеђује вријеме; живјеће Николина прича барем до Адамове старости, јер је на Адама адресирана, њему пренесена, па ће кроз њега и живјети: „Не могу да се науживам милине кад чујем како људи, и кад теби буду моје године, слушају шта зборим." Прича живи кроз оне који је преузимају, памте и преносе.

Никола и његова прича носиоци су трагичног осјећања живота: „А ја црну воду пијем откад памтим себе", вели Никола сјећајући се дјетињства и трагичне родитељске смрти - очеве на багремовом коцу и мајчине, изгубљене негдје у лудилу. Багрем је и у Николином сну симбол родитеља:

Док сам био млађи, често сам их сањао, а два пута исто, што, ето, нисам заборавио ни сад, пред полазак. Отац у великој шубари, плази језик и сав искићен јатаганима. Није отац, већ багрем, расцветао се, а само неколико листића на њему. Багрем има шубару, изубадан је јатаганима, а хода. И две раскрвављене руке, без тела и главе, беру са њега беле гроздове. Знао сам да је багрем отац, а руке што су кучићи изуједали мати ми је.

Флорална симболика, толико честа у Коренима, продире и у Николин сан као знак тешке трауме из дјетињства.

Никола је, дакле, носилац смисла приповиједања; носилац метапоетске функције у Коренима.

Изразита је, међутим, неусаглашеност између јунака, Николе, и његовога гласа, посебно у прологу и епилогу. Никола говори као какав модеран, неоавангардан пјесник или писац из друге половине XX вијека, који је, безмало, испунио цијело стољеће.

Никола на крају романа добија још једну композицијску функцију - функцију аутора љетописа о Катићима у Прерову: „Ја што гребах овај љетопис јесам Никола." Зато је вријеме о којем се у Коренима приповједа - вријеме Николиног боравка у кући Катића у Прерову, између његова два преласка преко Мораве у различитом смјеру, односно посљедња деценија XIX вијека.

Никола је, очевидно, композицијски стуб Корена. Друго је питање да ли је тај композицијски носач увијек најбоље постављен; да ли је његова стилска орнаментика са њим усаглашена.

У вези с Николиним ликом скренули смо пажњу на значај, симболизацију и лиризацију простора у Коренима. Простор се, по правилу, лиризује и субјективизује, али добија и изразито функционално симболичко значење. Поновимо: Никола бјежи од ватре, прво из шанца у који је улетјело топовско ђуле, од пута и шума који горе, запаљеног овна, живог испеченог и сагорелог; бјежи од ватире, преко воgе и леga, преко залеђене Мораве, и доспијева у йоgрум куће Аћима Катића, у мрачан gоњи йростиор куће, што симболизује његову хйонску природу. Нико- 


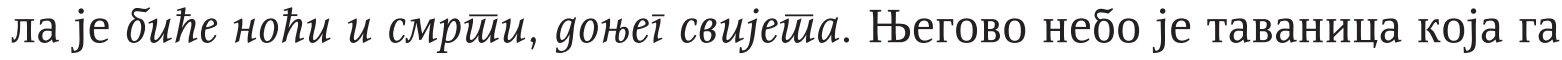
дијели од Симкине и Ђорђеве собе, што му омогућава увид у њихову брачну несрећу и изазива љубавну чежњу према Симки. На том небу су два загрљена мјесеца, што је метафора за Симкине дојке, предмет његове чежње. Никола се враћа из Прерова на Мораву кроз јарак - кроз земљу - што га опет везује за доњи свијет. Роман се одвија између два Николина преласка ријеке у два супротна смјера. Николина Србијица је каљогажа између три ријеке.

У знаку воде и воденице је и живот Аћимовог оца Луке Дошљака. Њега су, обескоријењеног и остављеног иза збјега, нашли крај ријеке, у корјеништу ишчупане врбе. Он живи на води и од воде, као бијели човјек у воденици, од ујма на брашно, уловљене рибе и онога што му Ката спреми и у млин донесе. Тема корјена и обескорјењења је метафоризована већ мјестом на којем је дјечак остављен и пронађен - тамо гдје је био корјен врбе - без презимена и свијести о родитељима и поријеклу. Он умире у воденици, у послу, у тренутку када покушава да подиже и наспе жито у кош, и налазе га мртвог, посутог житом. У изузетним приликама, као када му се родио син, Лука доноси кући рибу да прослави рођење, што је опет у знаку воде и ријеке.

Ката четрдесет дана чека Василија под тополом, за коју су чамце везивали и коју ће ишчупати и однијети ријека, а са њом и корјен бездјетног Василија. Ката посједује исконски матерински нагон за рађањем и обновом куће и породице, па укорјењује искоријењеног Луку и заснива лозу Катића.

Лука мијења простор око куће тако што ће засадити јасенове и подићи јабучар - неопходно и плодно дрвеће. И јабучар и јасенови ће се лајтмотивски понављати и у роману и добити симболичку вишезначност. У јабучару - међу грешним воћкама - зачедиће се Адам, уз присан доживљај архајске представе о сродности земље и жене, која се јавља барем два пута у роману. Нешто јабука из јабучара ће понијети Никола за вечеру, одлазећи из Прерова.

Оплођена Симка другачије, неупоредиво веселије и пуније доживља-

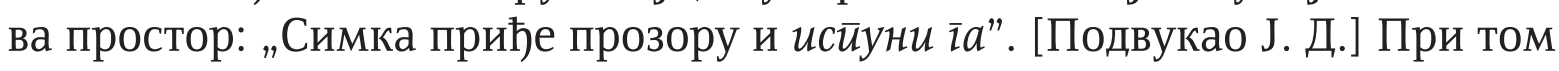
погледу кроз прозор „лако заборавља Ђорђа иза леђа, на кревету" и нада се да ће родити у „првој копњи кукуруза", а „багрем ће процветати".

Око Катића оџака, обраслог лишајем, облијеће рода, одакле јој је срушено гнијездо, запажа Аћим. Није ли и то наговјештај рођења, обнове гнијезда и живота, односно вид симболизације кућног простора.

Већ смо скренули пажњу на готово филмску симболизаиију иростиоpa о Бадњој вечери: врата остају отворена; у кућу улијеће хладан вјетар; споља се чује изгубљени лавеж пса. 
Простор се скупља и шири зависно од јунака и његовог доживљаја и виђења. Ево једног илустративног примјера Аћимовог доживљаја простора приликом његовог повратка у затвор:

Враћајући се у затвор, корачао је погурен, брзо, да га не загледа та чаршија, да не слуша шапутања иза леђа, свезаних руку. Пијаца се смањи, куће се примакоше и стиснуше једна уз другу, сиво, ниско небо примаче му Прерово, брест и све што је остало у оном сутону, он се једва провуче кроз затворска врата, у ходнику се одвезане руке млитаво замлатише и, кад угледа гомилу страха у гуњевима, усиљено се насмеја.

Други пут, при крају романа, Аћим такође осјећа како се простор мијења, овога пута ширећи се, али је то заправо ширење његовога доживљаја празнине, изазваног пражњењем апсане, јер сви су га напустили:

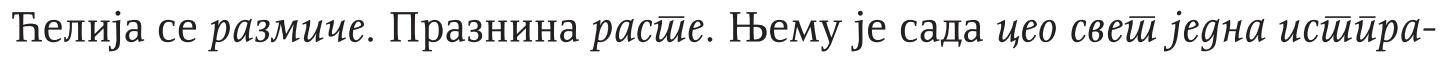
жњена ћелија. Она је некада била пуна људи. Сада је он сам у њој, а мрак плази зидовима и пустоши њене међе [Подвукао J. Д.].

Простор је наглашено симболизован и у Ђорђевом сижејном рукавцу. На путу, са Толом, спољашњи простор је опасан и ризичан, а Ђорђе је пун страха од којега ни пушка не брани. У механама, на преноћиштима, и унутрашњи простор је несигуран и опасан, па га замрачењем треба додатно заштитити.

Ђорђева несрећна сексуална иницијација догађа се у понижавајућем простору - на јаслама, у штали, у тами, под сукњом стрине Вишње и под заставом крављег репа, под тешким и загушљивим мирисима. Простор се може разумјети као пародија књишких, традицијских, идеализованих љубавних простора у сентименталистичкој традицији. Љубави ту нема, али има мржње, траума и трајних животних посљедица.

Своју и Симкину брачну постељу Ђорђе доживљава као гроб и мучилиште, па мучи и Симку на вијест о њеној трудноћи: „Толико смо година мешали ноге у овом гробу и ништа није никло."

На крају романа, враћајући се кући из апсане, Ђорђе прво свраћа на гробље, не би ли тамо сазнао да ли су у насталом помору остали живи Адам и Симка, а онда уистину, у мраку, упада у туђ, тек ископан гроб, на жива човјека који је уморан тамо прилегао. То је, наравно, симболична и вишезначна сцена којом се наговјештавају болест и близина смрти у својој кући, близина гроба, али се симболизује и Ђорђева животна ситуација двапут „прекланог” човјека. Први пут се тај епитет уз Ђорђа везује послије његовог првог искуства са стрином Вишњом, а онда при крају романа, када га тако види учитељ Андра. 
Простор, наравно, захтијева детаљније истраживање и засебан рад, али су ови примјери већ довољни да потврде његову субјективизацију, лиризацију и симболизацију у роману.

Мало је вјероватно да је Добрица Ћосић у првој половини педесетих година прошлога вијека имао прецизније теоријске представе о лајтмотиву, било као музичком, било као књижевном поступку и термину. Утолико нас више уистину задивљује мајсторско коришћење и провлачење лајтмотива кроз цио роман Корени. Лајтмотив је у овом роману неочекивано често и изузетно успјело средство лиризације и симболизације, по правилу велике и емотивне, и значењске сугестивности. Запажана је и истицана флорална симболизацја, али је о лајтмотиву мало писано; готово да се не спомиње. А лајтмотивски се понављају и јасенови, и јабучар, и брест, и багрем, и вода, односно ријека, и мјесец, али и дукати, и Симкине дојке, и биљно суво сјеме, и пијетао, и суво смиље, и варирана из различитих углова сјећања на Луку Дошљака.

Проблем лајтмотива у Коренима само смо назначили. За његову елаборацију потребан је најмање један засебан рад. Управо је то прилика да се критички развије лирска димензија овог Ћосићевог романа.

Корени су, несумњиво, роман са низом иновација на плану приповиједног поступка, понекад и данас неочекиваних и за почетак педесетих година поготово невјероватних, посебно за писца који је неприпремљен улазио у књижевност. Само је писац изузетног дара могао тако супериорно овладати слободним неуправним говором, такозваним доживљеним говором, симболизовати простор, увести полиперспективизам у приповиједање и с лакоћом се готово поигравати лајтмотивима са врло високим поетским и лирским учинком.

За нас је несумњиво да Бајка има у Ћосићевом опусу изузетно, а по значају за пишчеву интелектуалну и књижевну еволуцију - веома значајно мјесто. Бајка је једини Ћосићев роман који излази из историје и улази у „разисторију”; то је наш први, у цјелости, антиутопијски роман, и по томе има непроцењиво право првјенства у српској прози, односно у развоју српског романа. Истина, елементе антиутопије налазимо у Прољећима Ивана Галеба, али Десничин роман није у цјелости антиутопијски усмјерен. Има добрих разлога да се о елементима антиутопије говори и у Лелејској іори Михаила Лалића, кога с Ћосићевим романом повезује и лик ђавола. Код обојице писаца ђаво има позитивна значења, па је и мотив и лик ђавола у овим романима могућно разумјети као одјек Мефиста, односно Гетеовог Фаусши $a$, а код Лалића и као траг утицаја Достојевског, односно романа Браћа Карамазови.

Бајка је једини Ћосићев роман који није укоријењен у српску националну историју, већ има шире антрополошке, па и космолошке ам- 
биције. Милан Радуловић види Бајку као „можда једини космолошки роман у српској књижевности, роман који казује о настанку и нестанку света". Прво се приповиједа о претварању људске цивилизације у пепео и о пропасти човјека и историје, а потом слиједи сусрет с Анђамом, срби јанским Мефистом, у чијем су имену сједињени анђео (Ан) и ђаво (ђа). Ђаво јесте отпадник и побуњеник против Бога, Старца који је преваром потчинио себи сва, у почетку равноправна, духовна бића и постао властодржац и неприкосновени вођа. Анђама одбија да служи; не пристаје на космички поредак успостављен преваром. Зато он гради простор слободе на дну ријеке, искључен из поретка на који не пристаје, а који је заснован на превари, потчињености и хијерархији. Човјек склапа гетеовски уговор с Анђамом, али и Анђама показује своја ограничења постајући неотпоран на новац и јевтине привлачности привида слободе у играчкама и бљеску бижутерије. И Анђама постаје деморалисан и наиван, а човјек остаје једини прави побуњеник и приврженик слободе који тражи правду и за Бога и за ђавола; који вјерује сновима барем колико и стварима и који ће самјеравати свијет најдужим кораком и слободним рукама. Људска тежња за слободом побјеђује страх и забране које је поставио Бог Старац. Човјек је искусио зла која се чине у име добра и упозорава на катастрофална искуства историје. Човјек остаје биће побуне и слободе.

Ћосић користи алегорију и алузију, као опробана средства сатире и антиутопије и вјероватно је међу првим српским интелектуалцима, поготову писцима, који је у „Museumu” и „Камонији” иронизирао и пародирао фашизам и комунизам, два тоталитарна система која су залудила и унесрећила свијет у XX вијеку, и то пише већ средином шездесетих година тога вијека.

Овим путем фантастике и антиутопије Ћосић није даље ишао: препустиће га другима, а сам ће се вратити имагинирању националне историје. Бајка је, уз то, књига јеретичког прелома и њоме почиње пишчева беспоштедна и недвосмислена побуна против идеолошких варки. То је књига својеврсног идеолошког самообрачуна, драматичног прелома и раскида из које ће изаћи цијела Ћосићева дисидентска публицистика. Зато Бајка нема свога романсијерског наставка: послије 1966. Ћосић није више имао потребе за алегоријом и алегоријском параболом. Послије Бајке он је у идеолошком погледу други, нов и непрепознатљив човјек.

Роману Бајка, раскиду с комунистичком идеологијом и сукобу са Јосипом Брозом претходила су два Ћосићева путовања. Прво је путовање с Титом на броду „Галеб” у својству члана државне делегације која је обилазила афричке земље од 14. фебруара до 26. априла 1962. године. На „пловећем двору" пукла је раселина у пишчевој души до самога дна: 
На Галеб сам ступио као социјалист са сумњом и надом, а са Галеба сам сишао опљачкан, пребијен и понижен, бивши комунист згађен на баналност и кич пловећег двора брионског морнара, адмирала наше ескадриле мира.

Послије овог отрежњујућег путовања сломљени комуниста осјећа снажну побуду да види Дахау и Хитлерову кућу с бункером и Бергхофу. Ту је доживио нови и другачији потрес и ново драматично сазнање о свом вијеку - вијеку који је убио Бога и човјека. Након та два путовања Добрица Ћосић је постао други човјек, преображен у побуњеника и критички усмјереног интелектуалца; у писца који другачије гледа на човјека, историју, идеологију и друштвену стварност.

Зашто је Бајка морала настати кад је настала - послије Ћосићевог путовања са југословенским предсједником и маршалом на броду Галеб по несврстаним земљама? Прву критику тога путовања на предсједничком броду написао је сам путник - Добрица Ћосић, а та критика је постала побуна већ у роману Бајка и трајаће до краја пишчевог живота. Без путовања Галебом Бајке вјероватно не би било, а можда ни побуне; не барем 1966. године. То је побуна свједока, учесника у револуцији и на путовању Галебом; побуна анђела отпадника. Отуда похвала Анђами и разумијевање за њега. Отуда виђење Бога Старца као преваранта који покорава све равноправне духове.

У Баји, Ћосић посматра човјека као антрополошку загонетку. Анђама јесте моравски Мефисто, али је све вријеме ријеч о човјеку уопште, па и о (раз)историји свијета. Ћосић је наслутио оно што ће Пекић звати решавање антрополошке једначине, написавши прву српску романсијерску антиутопију и једну од првих књига побуне против Јосипа Броза Тита, што је било толико неочекивано и невјероватно да књига није благовремено ни прочитана и протумачена. Тито ће остати Ћосићев проблем и загонетка до краја пишчевог живота; можда и до посљедње, судбинске тачке.

Може се оспоравати значај Бајке за Ћосићево стваралаштво: тим путем романсијер није даље ишао, па је тај приповједачки модел самим тим непродуктиван. Из Бајке, међутим, излази цијела Ћосићева побуна, па и побуњеничка публицистика. Без Бајке не би било ни Грешника, ни

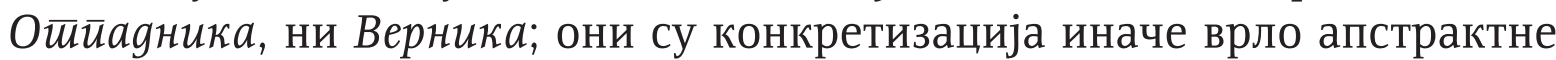
Бајке. У тој апстракцији је њена главна слабост. Она нема оних за Ћосића карактеристичних, индивидуализованих конкретних, појединачних ликова и судбина, укоријењених у домаће тло и историју, који би се кроз роман могли пратити. Роман побуне нема Ћосићу својствених драмских сукоба. Бајка нам данас личи на потенцијално складиште могућих, а неразвијених романа и романсијерских рукаваца, без конкретних индиви- 
дуализованих јунака који се памте, без драмских заплета и судбина. Она је замишљена као алегоријско-параболичко сатирично путовање.

Бајка је била својеврсна пишчева „помамна катарза”. Тек послије Бајке, послије побуне и идеолошког очишћења, Ћосић се могао свом стваралачком снагом вратити Првом свјетском рату и написати своје ремек-дјело - Време смрйи. Данас се, наиме, зна да је Ћосић покушао да одмах послије Корена настави своју сагу о Катићима и Дачићима. Није ишло. Осјећао је озбиљне идејне проблеме. Зато се вратио свом животном искуству и написао Деобе, веома драгоцјен роман чији ће се наслов памтити као српски архетип. Али већ са завршетком Корена, а нарочито послије Деоба, Ћосић је слутио да мора успоставити књижевну визију свога вијека чији би временски почетак био у Коренима - посљедња деценија XIX вијека - а романи Далеко је сунще и Деобе нашли би касније своје мјесто у том романсијерском циклусу. Недостајала је катарза, превасходно - идеолошко очишћење. А оно је дошло с Бајком.

Тек послије Бајке, послије јавне побуне и идеолошке катарзе, нестале су све идеолошке препреке за приступање теми Првог свјетског рата. Тек тада грађа за Време смрйи није пружала отпор. Зато је Бајка изузетно значајна за романсијерску еволуцију Добрице Ћосића. Прије Бајке и прије пишчеве „помамне катарзе” није могло бити написано Bpe-

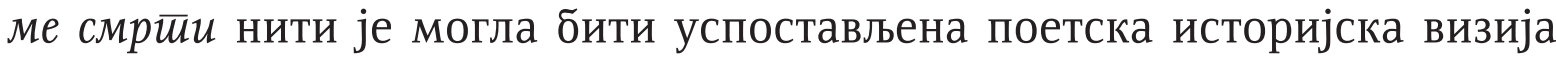
$\mathrm{XX}$ вијека. А корјени те визије, њен гранични и угаони камен, јесте први Ћосићев роман о Катићима и Дачићима, роман Корени. Зато су ова два романа преважна за Ћосићево еволуцију и његово успостављање књижевне визије епохе.

Мало је писаца таквог епског замаха и такве енергије као што је био Добрица Ћосић. Он је књижевно успоставио епоху и иза себе оставио снажну и упечатљиву слику XX вијека, и Србије и Срба у томе вијеку. Њему припада заслуга што је први проблематизовао смисао жртве и партизанског морала, уздигавши жртву до трагичних висина; што је изнутра дочарао унутрашње напрслине у идеализованом партизанском покрету (Далеко је сунще); што је увео полиперспективизам и тековине модерног романа у српски роман (Корени); што је активирао архетип деоба који је прихваћен као оличење националне судбине (Деобе); што је написао први српски антиутопијски роман (Бајка); што је вратио достојанство трагедији Првог свјетског рата и њоме оплеменио српску прозу оства-

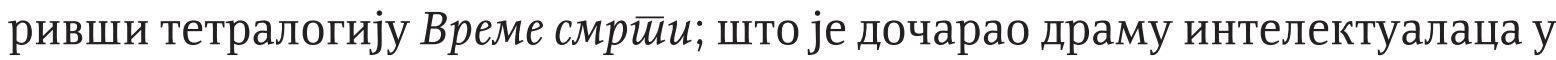
идеолошким маглама вијека, у судару с искушењима догме, робије и побуне (Време зла); што је дочарао проклетство и искушења власти и драму односа човјек - власт (Време властии I и II); што је отворио многе табу теме и убједљиво остварио трагичну визију историје свога народа, наро- 
чито у XX вијеку; што је књижевно успоставио епоху. Ћосићу припада признање за борбу за књижевни модернизам; за супротстављање догматизму; за часно свједочење о догађајима у Мађарској 1956. године; за спремност на жртвовање зарад истине о разбијању земље и о злочинима над Србима на Косову и Метохији; за супротстављање неприкосновеном властодршцу и за разбијање идеолошке магле.

Jovan M. Delić

THE NOVELS ROOTS AND A FABLE AS THE CRUCIAL WORKS IN DOBRICA ĆOSIĆ'S DEVELOPMENT AS A NOVELIST

\section{Summary}

The novels Roots and A Fable are of special importance to Dobrica Ćosić's development as a novelist. In Roots Ćosić began his "roman fleuve" on the Katić family and opened his broadest novelistic field. It was through that family saga that he constructed a vision of the history of the Serbian people from the late $19^{\text {th }}$ and the entire $20^{\text {th }}$ century. In Roots Ćosić discovered and applied modernist fictional techniques, the most important among which is polyperspectivism, achieved a high level of poetic, lyrical prose, rhythmical storytelling, especially in the prologue, he accopmlished a symbolisation of nature and space, and in the dramatic storyline, full of conflicts at several levels, he realised the dramatic potential of the novel. The writer expertly uses free indirect discourse and the stylistic devices typical of poetic lyrical discourse, especially metaphor. It was not easy for Ćosić to return to the topic of World War One. Therefore it was necessary for him to liberate himself from his ideological and social utopias. He achieved that in his novel A Fable. Perhaps it is not Ćosić's finest fiction, but it is a novel of utmost importance to his spiritual liberation and development as a novelist. It was only after A Fable that Ćosić was able to return to the early $20^{\text {th }}$ century and construct a literary vision of the bloody age of World War One. Without his passage through A Fable, it would have been impossible. 